\title{
CERCARIAE OF THE LAKES MAARSSEVEEN (NETHERLANDS) INFECTING BITHYNIA SPP. (GASTROPODA: PROSOBRANCHIA) AND PHYSA FONTINALIS (GASTROPODA: PULMONATA)
}

\author{
by

\begin{abstract}
STEF M. A. KEULEN
Department of Aquatic Ecology, University of Amsterdam, Kruislaan 320, 1098 SM Amsterdam, The Netherlands
\end{abstract}

\begin{abstract}
In 1978 cercariae have been collected from four species of freshwater snails in two lakes near Utrecht (Netherlands). Eleven species are recorded, of which six are described in detail. Five of these are new: Cercaria gutta n. sp. (Psilostomidae), C. cana n. sp. (Notocotilydae), C. quadrata n. sp. (Pleurogenetinae), $C$. abdita n. sp. and $C$. dyjannae n. sp. (both probably belonging to the Plagiorchiida, because they show characters of the group of Xiphidocercariae). Of $C$. dyjannae only the metacercarial cysts have been found.

The sixth cercaria described is that of Psilochasmus oxyuris (Creplin, 1825).
\end{abstract}

\section{RESUME}

Des cercaires ont été collectionnées en 1978 sur quatre espèces de Gastéropodes d'eau douce de deux lacs près d'Utrecht (Pays-Bas). Onze espèces sont signalées, dont six sont décrites de manière détaillée. Parmi ces six espèces, cinq sont nouvelles: Cercaria gutta n. sp. (Psilostomidae), C. cana n. sp. (Notocotilydae), C. quadrata n. sp. (Pleurogenetinae), C. abdita n. sp. et $C$. dyjannae n. sp. (ces deux dernières cercaires appartiennent probablement aux Plagiorchiida, car elles présentent des caractères propres au groupe des Xiphidocercariae). En ce qui concerne $C$. dyjannae, seulement les métacercaires enkystées ont été découvertes.

Enfin, la sixième cercaire décrite dans le présent travail, est celle de Psilochasmus oxyuris (Creplin, 1825).

\section{INTRODUCTION}

The purpose of the present investigation was an inventory of the cercariae from the following snail hosts: Bithynia leachi (Sheppard, 1823), B. tentaculata (Linnaeus, 1758), Potamopyrgus jenkinsi (Smith, 1889) and Physa fontinalis (Linnaeus, 1758).

Two lakes were sampled: Lake Maarsseveen I and Lake Maarsseveen II. These lakes are situated at a distance of about $75 \mathrm{~m}$ of one another and about $2 \mathrm{~km}$ north of Utrecht. Lake I only receives its water from rain and upwelling and therefore is clean and oligotrophic. Lake II receives its water from the river Vecht and is polluted and eutrophic.

In the period March up to the first weeks of August 1978 samples of prosobranchiate snails and Physa fontinalis were taken from five stations in Lake I and from four stations in Lake II. Altogether collections were made at eleven dates, but I did not visit all stations on every date.

\section{MATERIAL AND METHODS}

The snails were found on stones, pieces of wood and the like along the shore. They were taken to the laboratory and stored in glass containers, separated according to species. I kept them in a room that was illuminated twelve hours a day, at temperatures of about $16^{\circ} \mathrm{C}$.

The containers were examined daily for cercariae. Within a few weeks to a few months the snails were killed and examined for the presence of cercariae.

Cercariae were studied under cover-glass $(18 \times 18 \mathrm{~mm})$ in water and in $0.7 \%$ or $1.0 \% \mathrm{NaCl}$, and stained in $0.1 \%$ neutral red and $0.005 \%$ nile blue sulphate.

The sporocysts, rediae, cercariae and metacercariae were measured under cover glass, in very little water in order to keep them fully extended. The measurements are presented in $\mu \mathrm{m}$.

\section{RESULTS AND DESCRIPTIONS}

The following prosobranchiate snail species were collected: Bithynia leachi, B. tentaculata and Potamopyrgus jenkinsi. Of $B$. leachi, 384 specimens were examined, $70(18.2 \%)$ contained cercariae and $33(8.6 \%)$ contained metacercariae. Of $B$. tentaculata, these numbers were $207,8(3.9 \%)$ 
and $28(13.5 \%)$, respectively. In 134 specimens of $P$. jenkinsi examined, no cercariae or metacercariae were found.

Of Physa fontinalis (Pulmonata), 123 specimens were dissected. Cercariae occurred in 1 specimen $(0.8 \%)$, metacercariae in $29(23.6 \%)$.

Alltogether, eleven identifiable species of cercariae, recorded in the sequel, have been encountered. Only those metacercariae that belong to the cycle of the cercariae described, are further mentioned and figured in this paper, with the exception of Cercaria dyjannae, of which only the metacercarial stages are known.

\section{Cercaria of Psilochasmus oxyuris (Creplin, 1825). Figs. 1-4}

This large gymnocephalous cercaria was found once, in a specimen of Bitbynia leachi (height of shell $6 \mathrm{~mm}$ ) caught in Lake I on April 26th and dissected on July 17 th.

$\mathrm{R}$ ed i a (fig. 4, measurements in table $\mathrm{I}$ ). Rediae occurred in the proximal part of the digestive gland of the snail. They are hyalinewhitish, elongated, and have a thin body wall; the body often shows irregular constrictions. The maximal number of cercariae found within one redia was 20 immature and 2 mature specimens.

Cercaria (figs. 1 and 2, measurements in table I). - The oval, flattened body is brownishgrey in colour. The tail is surrounded by a broad, more or less dorsoventral fin fold which is broadest at its terminal end. It is cast off easily and may still show contractions after 24 hours.

The ventral sucker is situated well behind the middle of the body. Around its inner margin at least eight rows of spines seem to be present. One row of similar structures can sometimes be observed around the inner margin of the oral sucker.

The digestive system is rather conspicuous. The subterminal oral opening and short prepharynx are followed by a very muscular pharynx and a broad oesophagus, that divides well before the ventral sucker into two narrower caeca that end in the proximal part of the body.
The excretory vesicle is V-shaped. On its dorsal side there is a small cavity, from which a canal extends into two branches. The two dark, broad, primary excretion canals can be seen extending along the oesophagus up to the posterior rim of the oral sucker, where they seem to fuse at the dorsal side. At the level of the posterior end of the pharynx each canal gives off a small, ventrally directed, blind branch. The number of flame cells that could be detected was 20 in each half of the body; very probably there are more.

Penetration glands were not observed. In each half of the body a pattern of two longitudinal bands is visible, of which the lateral are darker than the median ones. These bands consist of many cells, brownish-yellow in colour and filled with small rods.

About ten mature cercariae of this type were free in the digestive gland of the host. Cercariae that had actually emerged from the snail were not observed.

Met a cercaria (fig. 3, measurements in table I). - Two encysted cercariae were found in the host specimen in which the rediae had developed. They were considered to belong to the present species because of their large dimensions, the branched primary excretory canals and the structure of the rim of the ventral sucker. The wall of the cyst is hyaline and very resistant against pressure.

\section{TABLE I}

Measurements (in $\mu \mathrm{m}$ ) of the cercaria of Psilochasmus oxyuris.

\begin{tabular}{|c|c|c|c|}
\hline & mean & range & $N$ \\
\hline \multicolumn{4}{|l|}{ redia (alive) } \\
\hline body & $2088 \times 396$ & $1800-2700 \times 336-504$ & 4 \\
\hline pharynx & $56 \times 54$ & $54-60 \times 48-60$ & 4 \\
\hline caecum & $430 \times 48$ & $380-480 \times 24.72$ & 2 \\
\hline \multicolumn{4}{|l|}{ cercaria (alive) } \\
\hline body & $1510 \times 585$ & $1272-1800 \times 540-600$ & 4 \\
\hline tail & $978 \times 147$ & $900-1200 \times 120-180$ & 4 \\
\hline oral sucker & $172 \times 162$ & $132-216 \times 132-204$ & 4 \\
\hline ventral sucker & $300 \times 282$ & $264.384 \times 252-312$ & 4 \\
\hline pharynx & $117 \times 114$ & $108-132 \times 96-132$ & 4 \\
\hline \multicolumn{4}{|l|}{ cyst } \\
\hline external diameter & 444 & 432.456 & 2 \\
\hline thickness of wall & 24 & 24 & 2 \\
\hline
\end{tabular}


BIJDRAGEN TOT DE DIERKUNDE, 51 (1) - 1981
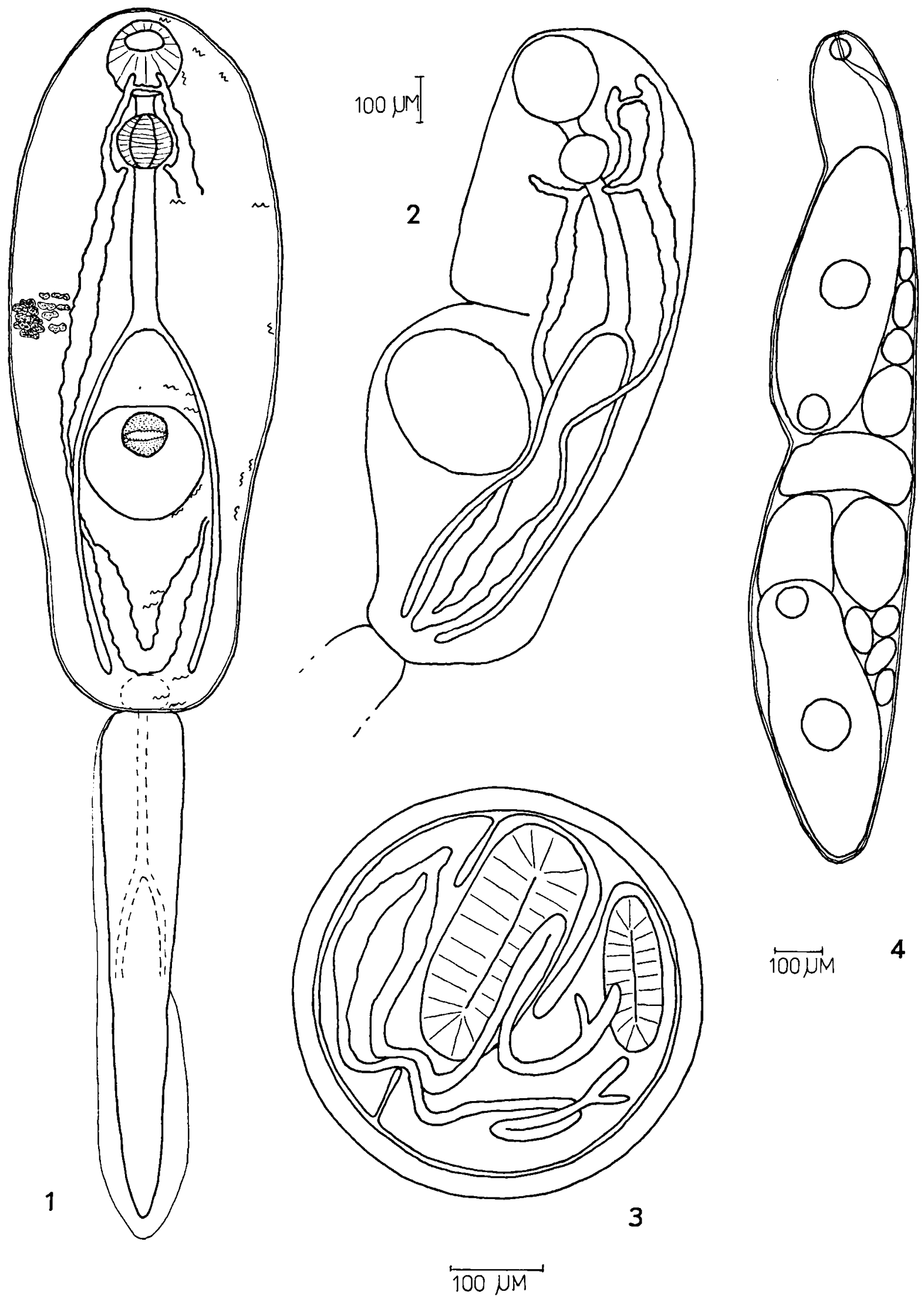

Figs. 1-4. Psilochasmus oxyuris (Creplin, 1825): 1, 2, cercaria; 3, metacercaria; 4, redia. 


\section{TABLE II}

Comparison of measurements (in $\mu \mathrm{m}$ ) of the cercaria of Psilochasmus oxyuris.

1, Wiśniewski, 1958;

2, Keulen, unpublished, measurements under cover-glass;

3, Van den Broek (pers. comm., 1979), measurements under cover-glass.

\begin{tabular}{|c|c|c|c|}
\hline & 1 & 2 & 3 \\
\hline \multicolumn{4}{|l|}{ redia } \\
\hline body & $1000-1900 \times 160-250$ & $1800-2700 \times 336.504$ & $2300-2760 \times 276-311$ \\
\hline pharynx & $70 \times 70$ & $54-60 \times 48.60$ & not measured \\
\hline \multicolumn{4}{|l|}{ cercaria } \\
\hline body & $460-1100 \times 120.300$ & $1272.1800 \times 540.600$ & $863-920 \times 276.522$ \\
\hline pharynx & 50 & $108-132 \times 96-132$ & $57-83$ \\
\hline oral sucker & $90-120 \times 90.130$ & $132.216 \times 132.204$ & $114.125 \times 117.140$ \\
\hline ventral sucker & $160-200 \times 170-200$ & $264-384 \times 252.312$ & $117-203 \times$ not meas. \\
\hline tail (length) & \multirow{2}{*}{$530-770$} & $900-1200$ & $690-920$ \\
\hline metacercaria & & & not present \\
\hline external diameter & $330-350$ & $432-456$ & \\
\hline thickness of wall & 25 & 24 & \\
\hline
\end{tabular}

B ehaviour. - As I found this species only once, in dissected material, details of its behaviour were not obtained. The cercariae out of the dissected snail were not very active, they sometimes swam slowly with contracted body. The cercariae lost their tails within ten minutes but did not encyst.

Comparis on with the description by Wiśniewski (1958). - Morphologically the cercariae described above are very similar to those of Wiśniewski, however there are some differences.

1. The most striking difference is the size of the cercariae; Ps. oxyuris from Maarsseveen is by far the larger.

On 18 July 1979 a second infection by $P$.s. oxyuris larvae was found in a Bithynia leachi from Lake II. These cercariae were larger than Wiśniewski's ones and smaller than those that I found in 1978 (Van den Broek, pers. comm.). The measurements are compared in table II and show a certain overlap.

2. The redia in the description of Wiśniewski has posterior lappets, lacking in the redia of $P s$. oxyuris from Maarsseveen.

3. Ps. oxyuris in the description of Wiśniewski has an I-shaped excretory vesicle, the excretory vesicle of Ps. oxyuris from Maarsseveen is V. shaped.
4. I observed spine-like structures in the suckers; Wiśniewski saw bundles of muscles in the ventral sucker, but he writes about these:

"In optical section bundles of these muscles form lines and rows which look like a system of spines but are in fact the longitudinal and transverse muscles seen in optical section" (Wiśniewski, 1958: 282).

5. According to Wiśniewski, Ps. oxyuris develops in Bithynia tentaculata, in the Lakes Maarsseveen it was found in B. leachi.

Despite these differences I am convinced that the cercaria described above is that of Ps. oxyuris.

Cercaria gutta n. sp. Figs. 5-10

This gymnocephalous cercaria has also been found only once, after dissection (August 14th), in a Bithynia tentaculata from Lake I, sampled July 19th.

R e dia (fig. 7, measurements in table III). Rediae occur in the digestive gland and the albumen gland of the host. They are elongated, hyaline, with a rather thick wall $(12-30 \mu \mathrm{m})$. The body has a collar and two locomotory appendages. In young rediae the proximal end is tapering, in mature ones it is broadly rounded. There is a globular pharynx and a broad intestine, that nearly extends to the posterior end of the body. The intestine is often filled with dark contents. 
There are up to 28 immature and up to seven mature cercariae in a full-grown redia, and also about 20 germ balls which are confined to the posterior end. Young rediae move about very actively, older ones hardly move.

Cercaria (figs. 5, 6, 8, 9, measurements in table III). - The cercaria has a very mobile body (figs. 8 and 9) and when at rest it appears dropshaped (fig. 5). Four darkly pigmented and lobed gland masses, concentrated in four bands, extend longitudinally along the body, the remainder of the body is white. The separate gland cells are elongated and seem to open by pores in the skin. There are also ducts that run forward from these gland masses and open near the oral sucker.

The cuticle bears no spines but has a varying number of flattened, broad cuticular projections.

The ventral sucker is the smaller one and lies well behind the middle of the body. Both suckers are surrounded by flattened scales: there is a collar of scales surrounding the oral sucker (fig. 6), and three rows of smaller scales surrounding the ventral one.

The four bands of glands already mentioned partly obscure the digestive system. There is a prepharynx and a pharynx, the latter is muscular. The oesophagus divides before the ventral sucker.
The caeca probably terminate on the level of the excretory vesicle.

This vesicle is rectangular in shape. Dorsally to it there is an accessory vesicle that leads into the longitudinal canal within the tail. The primary excretion canals, the walls of which could not be seen, are filled with refractory granules $(1-5 \mu \mathrm{m})$. The exact course of these canals could not be followed; in fig. 5 this is indicated by dashed lines. In each half of the body eight flame cells were seen; the flame cell formula $2[(2+2)+(2+2)]$ $=16$ is very probable.

The tail is short and flattened, there is no fin fold.

I have not seen cercariae of this type that had left the snail spontaneously.

Metacercaria (fig. 10, measurements in table III). - The snail host when dissected appeared to contain several hundreds of thickwalled, oval cysts. The inner part of the cyst wall is red in colour under the light microscope and green when studied with phase contrast.

The metacercaria is colourless and fills the cyst nearly entirely. The two suckers and the excretion granules are the only organs visible through the cyst wall.

TABLE III

Measurements (in $\mu \mathrm{m}$ ) of C. gutta.

\begin{tabular}{|c|c|c|c|}
\hline & mean & range & $N$ \\
\hline \multicolumn{4}{|l|}{ redia (alive) } \\
\hline body & $1012 \times 221$ & $300-2100 \times 60-420$ & 10 \\
\hline $\begin{array}{l}\text { pharynx } \\
\text { cercaria (alive) }\end{array}$ & $61 \times 53$ & $39.75 \times 33.75$ & 10 \\
\hline body & $207 \times 110$ & $150-240 \times 96-120$ & 10 \\
\hline tail & $122 \times 33$ & $105-150 \times 27.45$ & 10 \\
\hline oral sucker & 45 & $42-48$ & 10 \\
\hline ventral sucker & 35 & $30-39$ & 10 \\
\hline \multicolumn{4}{|l|}{ cercaria (heat-killed) } \\
\hline body & $268 \times 134$ & $255.279 \times 129-141$ & 3 \\
\hline tail & $158 \times 39$ & $150.165 \times 33-42$ & 3 \\
\hline oral sucker & 48 & $45-54$ & 3 \\
\hline ventral sucker & 44 & $42-45$ & 3 \\
\hline pharynx & $30 \times 21$ & $30 \times \quad 18-27$ & 3 \\
\hline \multicolumn{4}{|l|}{ cyst } \\
\hline external diameter & $112 \times 122$ & $105.120 \times 114-129$ & 10 \\
\hline thickness of wall & $6-9$ & $6-9$ & 10 \\
\hline
\end{tabular}




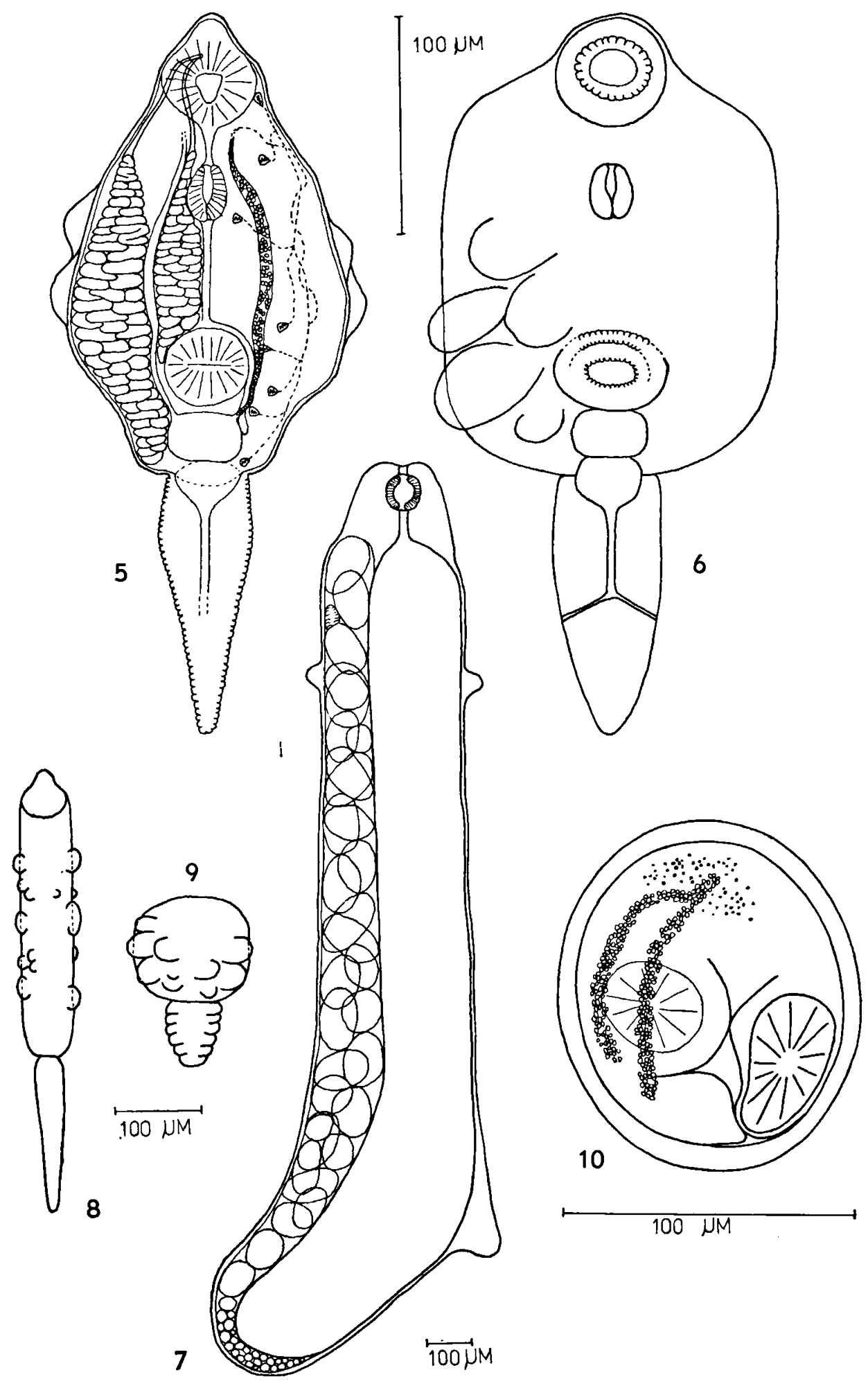

Figs. 5-10. Cercaria gutta n. sp.: 5, 6, 8, 9, cercaria; 7, redia; 10, metacercaria. 
Behaviour. - The rediae and cercariae are very active. The cercariae rarely swim, but creep by means of their suckers. Alternatively the body is extremely contracted and stretched (see figs. 8 and 9).

Comparis on with related species. - This cercaria is very different from all gymnocephalan cercariae hitherto described because of its broad, flattened projections. These projections are probably no tissues but secreted structures. The following observations confirm this opinion: (1) the number of projections is not always the same; in young animals they are lacking, in older animals projections are present; (2) full-grown animals in fresh preparations have fewer projections than they have some 30 minutes later; (3) the projections are not placed symmetrically and they are always seen in combination with the four cystogenous gland masses (see figs. 5, 6, 8 and 9).

Apart from the cuticular projections, the dark gland masses are very characteristic. Wikgren (1956) described Cercaria C Wikgren; according to his drawing this species has four gland masses. Because Wikgren gave only a very short description without mentioning the measurements of the cercaria, I fail to identify C. gutta with Cercaria $C$.

In the literature consulted by me, only one other cercaria of this type, having conspicuous bands of glands, is described: C. tuberculata De Filippi. This cercaria has been described by several authors like De Filippi (1857), Lühe (1909), Mathias (1925), Dubois (1929, as C. belvetica XIX), Wesenberg-Lund (1934) and Emmel (1942).

All these authors describe or figure only two bands of glands. The descriptions by De Filippi and Lühe are very incomplete, it is not possible to state the differences between their forms and the present one clearly.

Mathias and Wesenberg-Lund found rediae that were much (up to three times) smaller than mine; the cuticle of their cercariae was covered with spines or acute papillae. Besides, both authors mentioned the presence of two, instead of four, anterior canals leading from the bands of glands to the oral sucker.

In the cercaria described by Emmel (Gymnocephale Cercarie 1), the digestive tract is shaped differently: the caeca are shorter and wider than those of C. gutta and an oesophagus is lacking entirely.

Thus the conclusion is: $C$. gutta is not identical with $C$. tuberculata. I consider $C$. gutta a hitherto undescribed form.

\section{Cercaria cana n. sp. Figs. 11-14}

This monostome cercaria belongs to the imbricata group as defined by Rotschild (1938). It was found only once, in a Pbysa fontinalis collected in Lake I on 22 March 1978, and kept in the laboratory during five weeks. Living cercariae were found after 19 days.

$\mathrm{R}$ e di a (figs. 12 and 14, measurements in table IV). - Redia occur in the digestive gland of $P b$. fontinalis. They are whitish in colour and sausageshaped. About half the number of the specimens had a globular to elongated, posterior appendix, separated from the rest of the body by a constriction (fig. 14). Probably, in juvenile rediae the germ balls are situated in this part (see fig. 12).

The pharynx is nearly globular and leads into a very short gut, which seems to extend hardly into the body of the redia. Collar and locomotory appendages are lacking. Mature rediae contain about 14-20 developing cercariae, within 6-7 of these distinct lateral eyespots and darker pigment can be observed.

Neither juvenile nor mature rediae did shor any movements.

Cercaria (fig. 11, measurements in table IV). - The mature cercaria has a flattened body, is lead grey in colour, whilst the tail is colourless. The body bears four longitudinal bands of dark brown pigment (fig. 11). These bands consist of little globular bodies, containing small quickly moving rods of pigment. The globular bodies seem to be linked by short ducts.

The median eyespot is situated dorsal to the pharynx. The lateral eyespots, which lie immediately behind it, are dark brown to black in colour and have a rather even structure. The median 


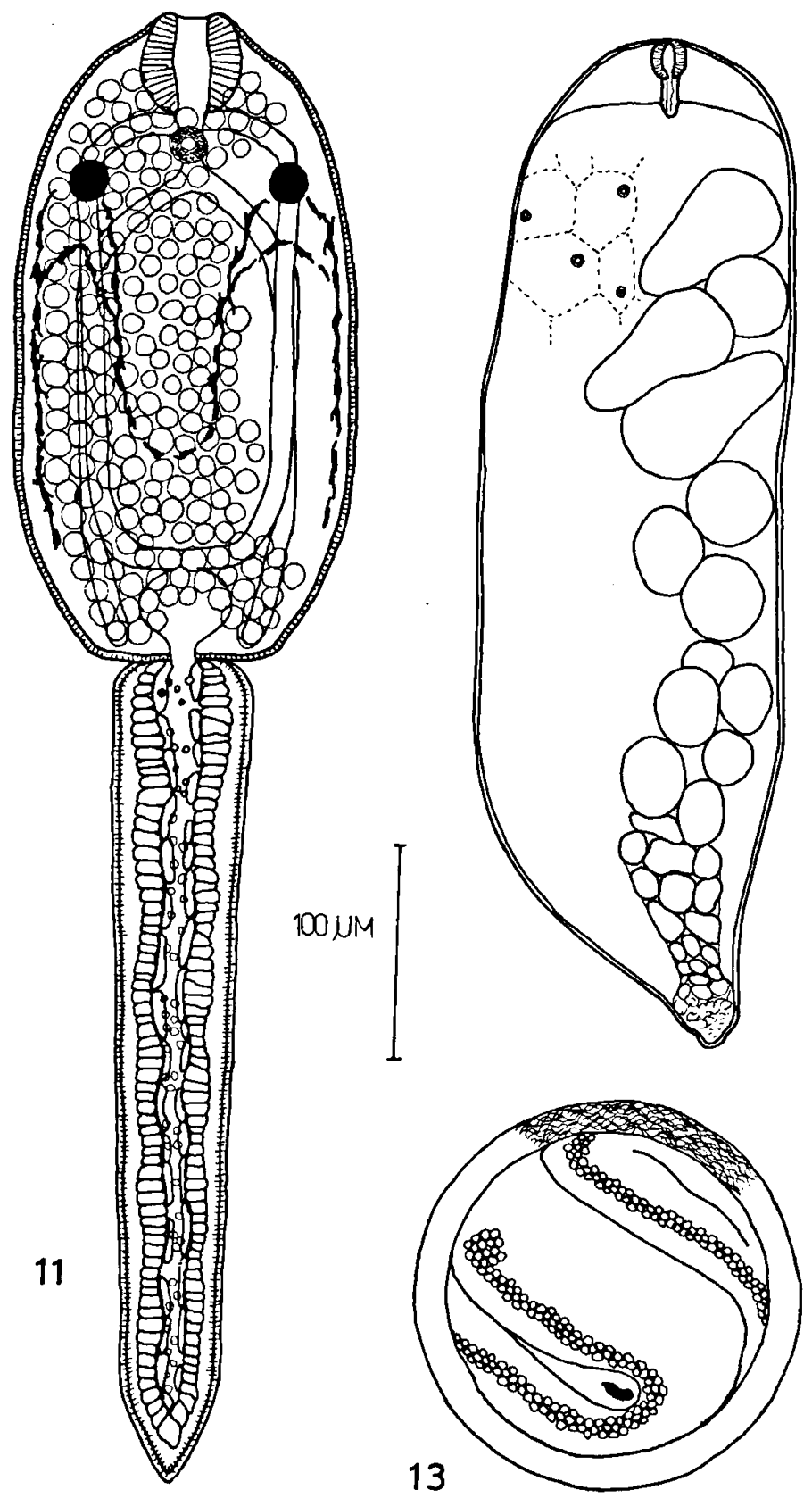

12

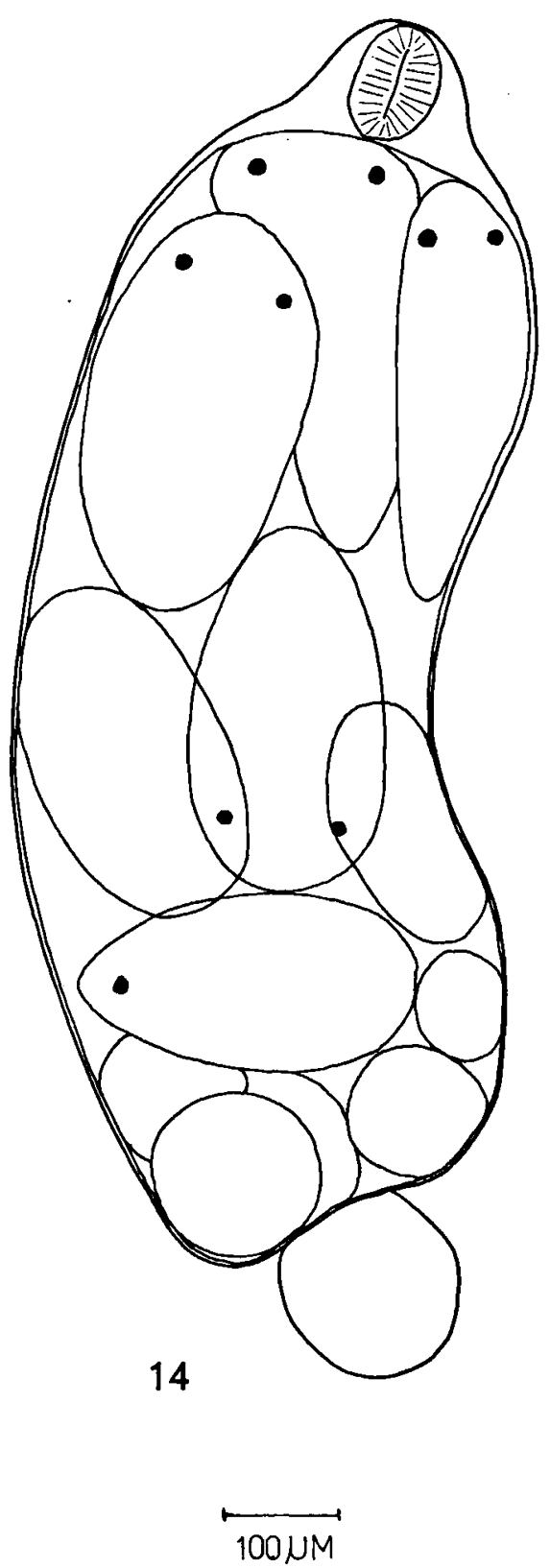

Figs. 11-14. Cercaria cana n. sp.: 11, cercaria; 12, 14, redia; 13, metacercaria. (Left scale applies to figs. 11 and 13 , right scale to figs. 12 and 14.)

eyespot is lighter in colour with a hyaline centre. In dorsal view the eyespots are globular, seen in lateral view they are drop-shaped with a caudally pointed end.

The mouth leads into a short pharynx, followed by an oesophagus that bifurcates immediately behind the median eyespot. The caeca run parallel to the longitudinal parts of the excretion canals and terminate on the level of the excretory vesicle.

The main collecting tubes of the excretory system form a closed loop and terminate in a common opening into a vesicle that is rounded to oval in shape. Anteriorly this loop extends to the level of the median eyespot and lacks a diverticulum (this 
is characteristic of the imbricata group of monostome cercariae). I was not able to observe secondary excretory vesicles and flame cells, because these were covered by a large number of rounded cystogenous cells. These cells are filled by small rod-like structures (bâtonnets) and in several cases seem to be arranged in transversal bands across the body of the cercaria.

In the centre of the tail a number of elongated cells occur, that have originated in 6-8 pairs. This symmetrical pattern fades in mature cercariae. The elongated cells are surrounded by a layer of shorter cells.

Metacercaria (fig. 13, measurements in table IV). - - Juvenile cysts are transparent, thickwalled. Eyespots, intestine and excretory vesicle are visible. Gradually the cyst becomes brown and opaque, the eyespots remaining visible as diffuse pigmented patches. Dried cysts seem to be covered by very thin spines (length 4-7 $\mu \mathrm{m}$ ). When dissecting the infected snail host, I found a number of these cysts in the tissues surrounding the mantle cavity.

B ehaviour. - The maximal number of cercariae that was observed to emerge during a day was 49 . They swim vigorously by means of a corkscrew movement of the tail. They encyst within ten minutes, and in the container the cysts were exclusively found on the bottom.
Comparis on with related species. - As regards its morphology and measurements, this cercaria closely resembles $C$. monostomi as described by Wesenberg-Lund (1934), Wikgren (1956), Meyer (1964) and others. C. monostomi, however, belongs to the monostomi group and the intermediate hosts of this species are species of the genus Lymnaea s.l.

Harper (1929) reports C. monostomi from Physa fontinalis, but this record is considered an error (Wikgren, 1956; Odening, 1966).

The cercaria of Notocotylus pacifer, which develops in $\mathrm{Ph}$. fontinalis, belonging to the monostomi group, is slightly smaller, and the redia has a conspicuous long gut with brown contents (Odening, 1966).

In his fairly recent surveys of notocotylid cercariae, Odening (1964 and 1966) mentioned no species of the imbricata group that develops in $P h$. fontinalis. I therefore consider this cercaria a hitherto undescribed form.

\section{Cercaria of Notocotylus imbricatus (Looss, 1893 ) sensu U. Szidat, 1935}

This monostome cercaria was found only once in Bithynia tentaculata collected from Lake I on April 26th and dissected on July 12th. Rediae were found in the digestive gland of the snail, the cercariae in its body cavity were immature. The morphology of both stages agreed with former de-

TABLE IV

Measurements (in $\mu \mathrm{m}$ ) of C. cana.

\begin{tabular}{|c|c|c|c|}
\hline & mean & range & $N$ \\
\hline \multicolumn{4}{|c|}{ redia (in $4 \%$ formalin of $80^{\circ} \mathrm{C}$ ) } \\
\hline body & $1055 \times 338$ & $844-1604 \times 288-424$ & 10 \\
\hline pharynx & $74 \times 64$ & $54-96 \times 54.75$ & 10 \\
\hline \multicolumn{4}{|c|}{ cercaria (in $4 \%$ formalin of $80^{\circ} \mathrm{C}$ ) } \\
\hline body & $298 \times 155$ & $243.339 \times 144.195$ & 10 \\
\hline tail & $338 \times 68$ & $285-372 \times 57-78$ & 10 \\
\hline oral sucker & $37 \times 40$ & $\times \quad 36-42$ & 10 \\
\hline \multicolumn{4}{|l|}{ cyst } \\
\hline external diameter & 150 & $135 \times 180$ & 10 \\
\hline thickness of wall & 16 & $9-24$ & 10 \\
\hline
\end{tabular}


scriptions, e.g. by Pike (1969). However, the diverticulum that is characteristic of this species was not yet visible.

Since the cercaria of $N$. imbricatus is the only species among the monostome cercariae that occurs in B. tentaculata (cf. Odening, 1964), there can be hardly any doubt of its identity. The species matures in ducks (Anas platyrbynchos) that occur regularly on the lake.

When compared with data from the environments of Amsterdam (Van den Broek \& Bruggeman, 1977) where N. imbricatus was found regularly in $B$. tentaculata, the incidence in the Maarsseveen Lakes is rather low (one snail infected out of 187 from Lake I).

\section{Cercaria of Pleurogenes claviger (Rudolphi, 1819)}

Throughout the period of research, this Xiphidiocercaria belonging to the virgula group was found several times in both lakes, but exclusively in Bithynia leachi. The morphology of sporocyst and cercaria is in agreement with those described by Grabda-Kazubska (1971) for this species, which she found in $B$. tentaculata. This host occurs in both Maarsseveen lakes and was dissected in sufficiently large numbers (207) but it never contained stages of $P$. claviger.

Of $B$. leachi, however, in Lake I two snails were infected out of 88 and in Lake II 45 out of 305 (2.3\% and $14.8 \%$, respectively). These data are in agreement with our observations that especially Lake II was frequently visited by frogs (Rana spp.), which are the final hosts of this species.

\section{Cercaria quadrata n. sp. Figs. 15-18}

This is a Xiphidiocercaria, belonging to the virgula group. It was found in eight specimens of Bithynia leachi and in one specimen of B. tentaculata, all collected on May 5 th in three collecting stations in Lake II.

S porocyst (fig. 18, measurements in table V). - Sporocysts occur in the digestive gland of the host. They are mostly white (some are light brown), thin-walled, and their shape is variable from elongated to nearly triangular. A full-grown sporocyst contains either three immature or two mature cercariae.

Cercaria (figs. 15-17, measurements in table V). - The animal is opaque, white, and has a flattened body. The anterior end is rounded, the caudal end is more or less rectangular. The body is covered by fine spines (fig. 15), placed in a regular pattern, laying within a thin cuticle. The tail bears no setae or spines and is attached ventrally. The ventral sucker is smaller than the oral one and lies just behind the middle of the body. The oral sucker contains a stylet (fig. 16) and a virgula organ with a rather big cavity (fig. 15) that can be closed.

Underneath the thin cuticle there are many opaque cystogenous cells that cover the internal organs. With difficulty I observed three pairs of penetration glands besides and behind the ventral sucker. The body further contains numerous small droplets (diameter $1 \mu \mathrm{m}$ ). In juvenile animals treated with neutral red, a rather constant pattern of red cells appears, in the body as well as in the tail (fig. 15).

Of the digestive apparatus the muscular pharynx and the oesophagus are visible. The latter is divided just in front of the ventral sucker. The caeca could not be observed to their full length. Of the excretory system only the U-shaped vesicle, its terminating pore (fig. 15) and the twisted primary canals were visible. The flame cells seem to be obscured by the layer of cystogenous cells.

B e h a vi o u r. - Many fresh cercariae were shed every day in the glass container. When swimming the cercaria could curve its body so that it appeared to be spherical, and it could lash the straightened tail. Creeping was hardly observed. When resting the cercariae assumed a typical position: the tail was hidden in the concave body (see fig. 17). No encystment occurred in the water.

Comparis on with related species. - This form is rather similar to the cercaria of Pleuro- 

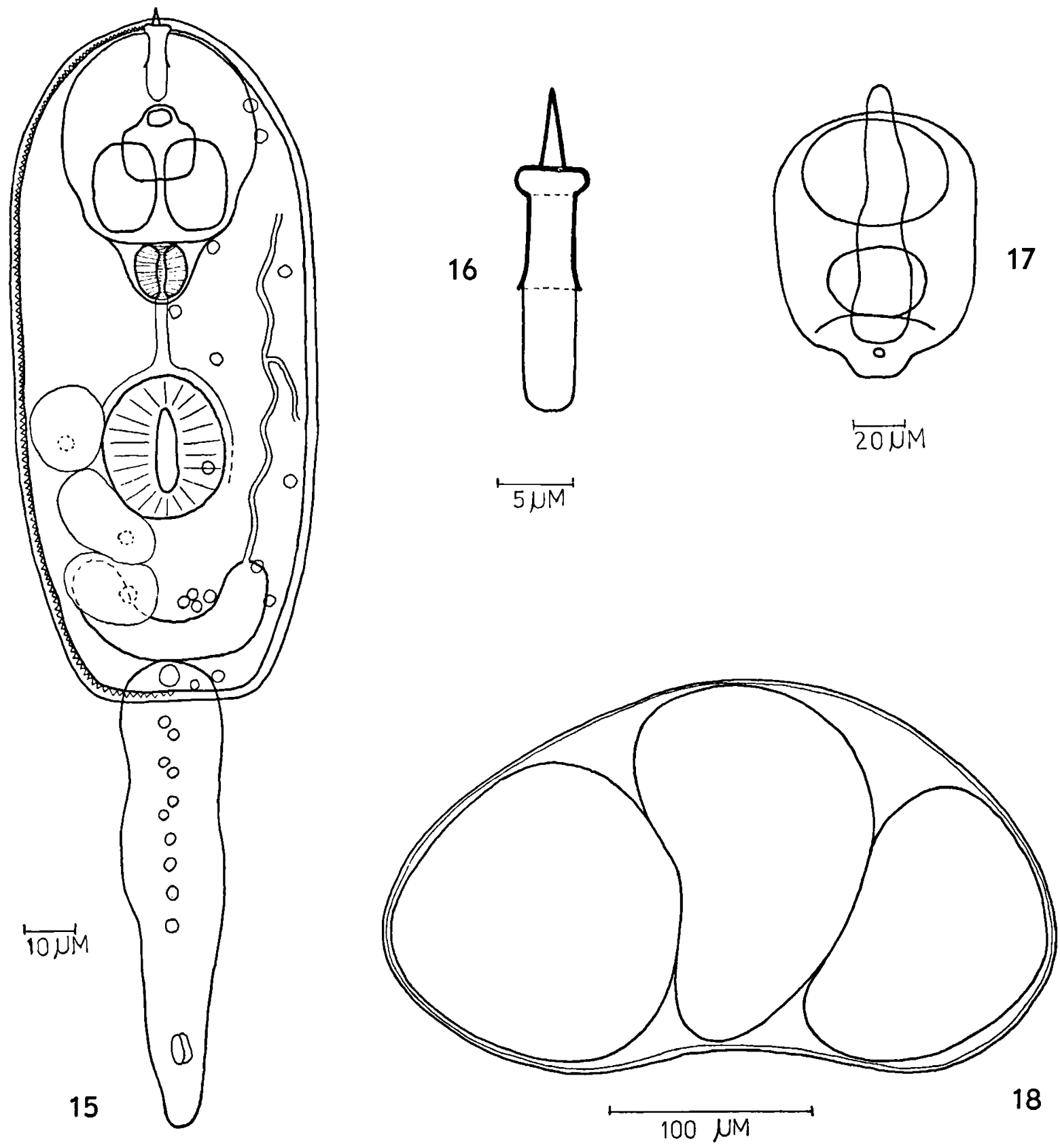

Figs. 15-18. Cercaria quadrata n. sp.: 15, 17, cercaria; 16, stylet; 18, sporocyst.

genes medians (Olsson, 1876) as described by Neuhaus (1941). There are some differences, however. The cercaria described by Neuhaus has a longer and stouter tail, and its stylet is longer; its excretory bladder is $\mathrm{V}$-shaped and it has four pairs of penetration glands. On the other hand, ac- cording to Grabda-Kazubska (1971) it is very difficult to distinguish between the cercariae of $P$. claviger and $P$. medians. In the present case, the former is very different from the one described above. Since in my opinion there can hardly be any doubt about the identity of the cercaria of $P$. cla- 
TABLE V

Measurements (in $\mu \mathrm{m}$ ) of C. quadrata.

\begin{tabular}{lccr}
\hline & mean & range & $N$ \\
\hline $\begin{array}{l}\text { sporocyst (alive) } \\
\text { body }\end{array}$ & $416 \times 205$ & $312-576 \times 156-264$ & 10 \\
$\begin{array}{l}\text { cercaria (alive) } \\
\text { body }\end{array}$ & $168 \times 85$ & $150-198 \times 57-111$ & 10 \\
$\quad$ tail & $108 \times 21$ & $69-135 \times 15-24$ & 10 \\
$\begin{array}{l}\text { oral sucker } \\
\text { ventral sucker }\end{array}$ & $63 \times 62$ & $54-69 \times 54-69$ & 10 \\
$\begin{array}{l}\text { pharynx } \\
\text { stylet (length) }\end{array}$ & $29 \times 32$ & $21-36 \times 14-48$ & 10 \\
\hline & $12 \times 12$ & $12 \times 12$ & 6 \\
\end{tabular}

viger, it is improbable that the cercaria described above belongs to the cycle of $P$. medians. For these reasons I consider this form as a separate species.

\section{Cercaria parva Khan, 1961}

Twice I found in Bithynia tentaculata from Lake I a Xiphidiocercaria of the microcotylea group. This form is similar to $C$. parva as described by Khan (1961) and by Pike (1967). Nothing is known about the life cycle of this species.

\section{Cercaria abdita n. sp. Figs. 19-24}

Three times this microcotylid species was found in Bithynia leachi, once from Lake I (7 June, dissected 9 August), twice from Lake II (10 May, dissected 3 and 6 August). The species is remarkable for the fact that the cercarial stage seems to be very short and that encystment apparently takes place in the same host individual where the sporocysts have developed.

Sporocyst (fig. 24, measurements in table VI). - The sporocyst is hyaline-whitish in colour. It may contain two developing cercariae, but the majority of sporocysts was filled by metacercariae, up to eight in number. Its body wall is very thin and often damaged when the snail host is dissected. On first view, therefore, the digestive gland of the snail host seems to contain free cysts only.
Cercaria (figs. 19, 21, measurements in table VI). - The body of the cercaria is dropshaped and opaque, when stretched it is round in transverse section. It is covered by small spines ( $3 \mu \mathrm{m}$ in length). The ventral sucker is the smallest, and situated in the middle of the body. The oral sucker contains a small stylet (fig. 20).

The tail is attached ventrally, its cuticle bears no spines or setae.

The digestive system consists of a subterminal oral opening, that leads into a thick-walled cavity (muscular prepharynx?), followed by a small pharynx. The oesophagus divides immediately in front of the ventral sucker in two caeca that terminate on the level of the middle of the excretory vesicle.

Besides the V-shaped excretory vesicle, that opens through a short canal between the body and the tail, nothing could be seen of the excretory system, because of the presence of many cystogenous cells in the body below the cuticle. Apart from these cells the body contains many small droplets (fig. 19).

B e h a vi o u r. - Only a few free cercariae were found between the host's tissues. These cercariae did not swim, but they were creeping very actively, often coiling their tails upwards. The majority of the free cercariae observed by me had lost their tail.

Met a cercaria (figs. 22, 23, measurements in table VI). - Hundreds of brownish cysts lie scattered between the body tissues of the snail. The 

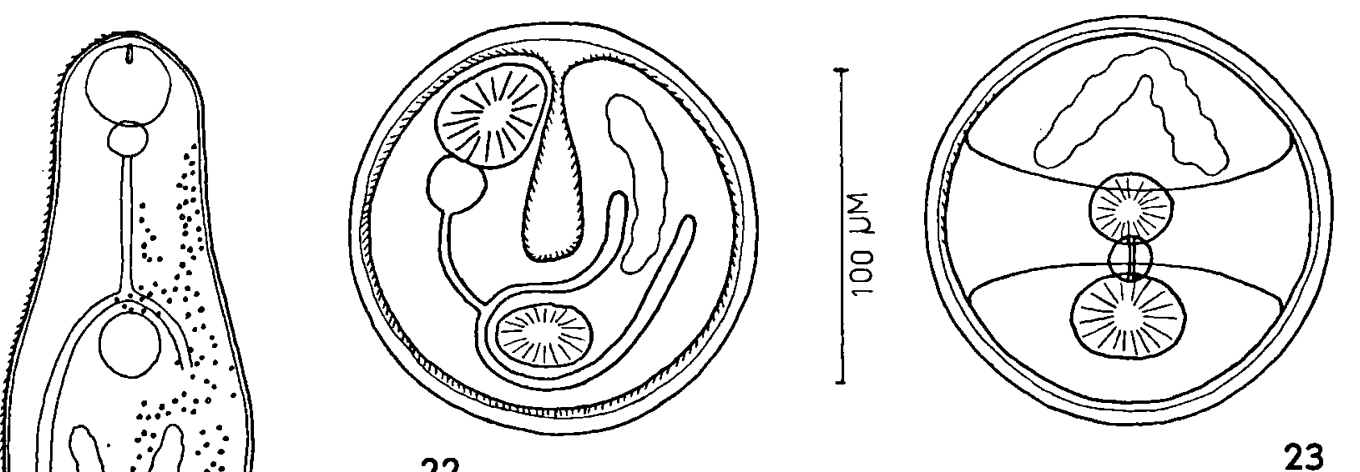

22

23

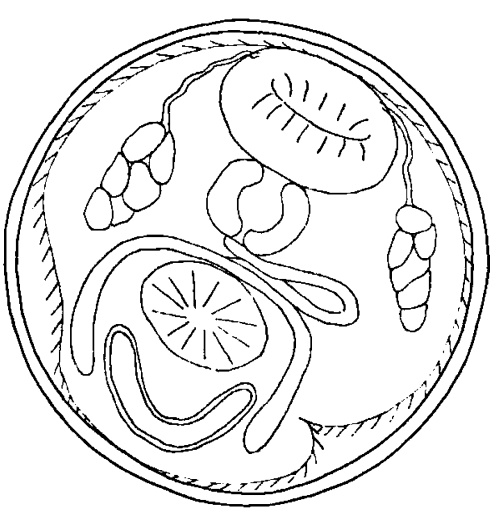

25

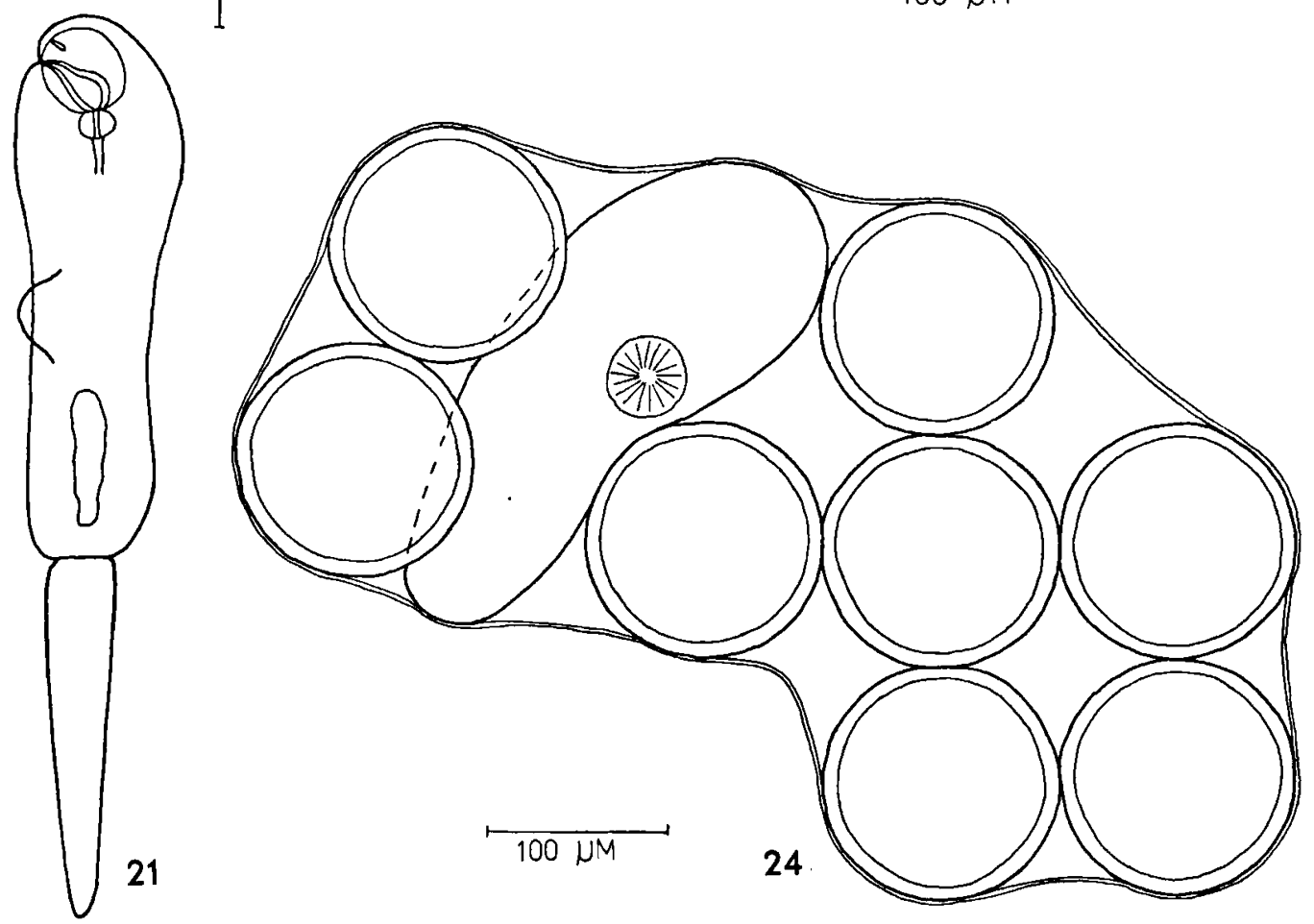

Figs. 19-24. Cercaria abdita n. sp.: 19, 21, cercaria; 20, stylet; 22, 23, metacercaria; 24, sporocyst.

Fig. 25. Cercaria dyjannae n. sp., metacercaria. 
Measurements (in $\mu \mathrm{m}$ ) of C. abdita.

TABLE VI

\begin{tabular}{lccr}
\hline & mean & range & $N$ \\
\hline $\begin{array}{l}\text { sporocyst (alive) } \\
\text { body } \\
\text { cercaria (alive) }\end{array}$ & $444 \times 239$ & $342-600 \times 225-260$ & 3 \\
$\quad$ body & $174 \times 77$ & $165-180 \times 69-84$ & 5 \\
tail & $111 \times 25$ & $93-120 \times 24-27$ & 3 \\
pharynx & $18 \times 15$ & $15-21 \times 12-18$ & 4 \\
oral sucker & 45 & $42-48$ & 5 \\
ventral sucker & 29 & $27-30$ & 5 \\
stylet (length) & 9 & 9 & 4 \\
cyst & & $111-135$ & 10 \\
external diameter & 127 & 6 & 10 \\
thickness of wall & 6 & & \\
\hline
\end{tabular}

cyst wall is rather homogeneous, and resistant to pressure. Often a thin outer membrane encloses the cyst wall. No movements of the metacercariae within their cysts were observed.

Comparis on with related species. - Pike (1967) described an animal (Microphallid cercaria sp.) with short caeca and without a stylet, so this is not the same species as I found. Therefore, I consider this form as hitherto undescribed.

\section{Cercaria dyjannae n. sp. Fig. 25}

This form is rather similar to the previous one, and was also found in Bithynia leachi, in three specimens from Lake II (collected on 10 May among 250 snails). Only encysted metacercariae were observed, several hundreds in each snail.

Metacercaria (fig. 25, measurements in table VII). - At first sight the cyst is nearly identical with that of the previous species. The metacercaria bears coarse spines, that are about $4 \mu \mathrm{m}$ long and have a basis of $1.2 \mu \mathrm{m}$ wide. The suckers do not differ clearly in size. A stylet was not observed.

The digestive system is plainly visible: a large pharynx, an oesophagus that divides just before the ventral sucker, and two large caeca that extend to the posterior end of the body. Of the excretory system only the vesicle can be seen, this is rather thick-walled and V- to Y-shaped.
On the level of the oesophagus at least four, but more probably six, pairs of penetration glands could be made visible by staining with nile blue sulphate. The ducts from these glands open near the oral sucker.

There was no trace of remains of sporocysts surrounding these metacercariae. They are described here because of their close resemblance with the former species. I have no indication that the sporocysts had originally developed within the same hosts.

Comparis on with related species. - This form differs from the previous one: (a) in the presence of penetration glands; (b) in the presence of a coarse spination: the spines themselves are larger and the distance between the spines is larger; (c) in the fact that the suckers are similar in size. It differs from the microphallid Pike (1967) described by its penetration glands and the long caeca.

In my opinion, this form has not been described before.

Derivatio nominis. - This species is named after Dyjanne Wildenborg.

\section{Cercaria micrura s.1. De Filippi, 1857}

This microcercous cercaria was found in two specimens of Bitbynia tentaculata, collected on 24 May (dissection 20 July) and 7 June (dissection 16 August), respectively, both from Lake I. 
TABLE VII

Measurements (in $\mu \mathrm{m}$ ) of C. dyjannae.

\begin{tabular}{lccr}
\hline & mean & range & $N$ \\
\hline $\begin{array}{l}\text { cyst } \\
\quad \text { external diameter }\end{array}$ & 108 & $90-120$ & 10 \\
$\begin{array}{l}\text { thickness of wall } \\
\text { metacercaria (alive) }\end{array}$ & 3 & $3-4$ & 10 \\
$\quad$ pharynx & $18 \times 21$ & $15-21 \times 18-24$ & 10 \\
$\quad$ oral sucker & $22 \times 34$ & $18-24 \times 24-42$ & 10 \\
$\quad$ ventral sucker & $24 \times 29$ & $18-33 \times 18-39$ & 8 \\
\hline
\end{tabular}

Its morphology was in agreement with the descriptions by Lühe (1909), Wesenberg-Lund (1934) and Pike (1967). Previous observations (Van den Broek, unpublished) have shown that in the Lakes Maarsseveen the cercariae of this type appear in larger numbers as summer advances, and that they are rather common during autumn.

It is generally assumed that $C$. micrura is the cercaria of Sphaerostomum bramae, a parasite of fish. The metacercariae occur in various species of snails. However, Kozicka (1959) has shown in a study of the adult forms in various fish hosts, that the genus Sphaerostomum Rudolphi, 1802 consists of several species. The descriptions of " $C$. micru$r a$ " may therefore cover more than one species of cercariae, of which the life cycles have not yet been studied.

\section{Cercariaeum bythineae Khan, 1961}

On two occasions, I found this form in Lake I: once in Bitbynia tentaculata, once in B. leachi, collected on 22 March and 24 May and dissected on 30 May and 16 August, respectively. The rediae occurred in the digestive gland.
In both cases, the cercariaeum was similar to $C$. bythineae as described by Khan (1961), except for the measurements that did not quite agree (for comparison see table VIII).

In vessels containing the infected snails, both Bitbynia species appeared to harbour cysts that very probably belong to this species. Cysts found in $B$. leachi had a slightly smaller diameter than those found in $B$. tentaculata, but the metacercariae from the former were developed further.

B e haviour. - The mature cercariae show a characteristic behaviour, adjusting themselves by means of the ventral sucker to the tentacles of the host. When this host meets another snail they were seen to attach to the head of this other specimen. A B. leacbi infected in this way was dissected 24 hours later. The cercariae were found still alive and unencysted among the snail's tissues.

\section{ACKNOWLEDGEMENTS}

It gives me great pleasure to acknowledge the invaluable help and patience of Drs. E. van den Broek. Furthermore, I wish to thank for their help the staff and all co-workers of the former Hydrobiology group of the Zoological Laboratory, presently Department of Aquatic Ecology.

TABLE VIII

Comparison of the dimensions (in $\mu \mathrm{m}$ ) of Cercariaeum bythineae, all animals heat-killed.

\begin{tabular}{lcccc}
\hline & & \multicolumn{2}{c}{ Khan (1961) } & Present paper \\
\hline & mean & range & mean & range \\
body & $440 \times 190$ & $386-460 \times 160-200$ & $592 \times 254$ & $494-732 \times 186-309$ \\
oral sucker & $71 \times 70$ & $60-83 \times 63-83$ & $99 \times 106$ & $87-114 \times 84-132$ \\
ventral sucker & 106 & $83-116$ & $131 \times 158$ & $129-144 \times 120-174$ \\
pharynx & $33 \times 38$ & $30-36 \times 36-46$ & $38 \times 40$ & $33-40 \times 30-51$ \\
\hline
\end{tabular}




\section{REFERENCES}

Broek, E. van den \& A. C. Bruggeman, 1977. Cercariae found in the region south-east of Amsterdam. Bijdr. Dierk., 46 (2): 171-179.

Dubois, G., 1929. Les Cercaires de la région de Neuchâtel. Bull. Soc. neuchâtel. Sci. nat., 53: 1-177.

EMmel, L., 1942. Die Cercarien von Bithynia tentaculata L. und B. leachi Leach aus einem Berliner Standort, ihre jahreszeitliche Verteilung und die Spezifität ihrer Anpassung an den Zwischenwirt. Zentbl. Bakt. Parasitenk., (I, Originale) 149: 81-98.

FILIPPI, PH. DE, 1857. Troisième mémoire pour servir à l'histoire génétique des Trématodes. Memorie Accad. Sci. Torino, (2) 18: 201-232.

GrabDA-KAZUBSKA, B., 1971. Life cycle of Pleurogenes claviger (Rudolphi, 1819) (Trematoda, Pleurogenidae). Acta Parasit. pol., 19: 337-348.

HARPER, W. F., 1929. On the structure and life histories of British fresh-water larval trematodes. Parasitology, 21: $189-219$.

KHAN, D., 1961. Studies on larval trematodes infecting freshwater snails in London (U.K.) and some adjoining areas. Xiphidiocercariae. Z. Parasitenk., Berlin, 21: 71-81.

KozICKA, J., 1959. Parasites of fishes of Druzno Lake. Acta Parasit. pol., 7: 1-68.

Lühe, M., 1909. Parasitische Plattwürmer, 1. Trematodes. Süsswasserfauna Dtl., 17: 1-210 (Fischer, Jena).

Mathias, P., 1925. Recherches expérimentales sur le cycle évolutif de quelques Trématodes. Bull. biol. Fr. Belg., 59: 1-125.

MEYER, P. O., 1964. Die Trematodenlarven aus dem Gebiete von Zürich. Vjschr. naturf. Ges. Zürich, 109: 277-372.

Neuhaus, W., 1941. Entwicklung und Biologie von Pleurogenes medians Olss. Zool. Jb. (Syst.), 74: 207-242.

Odening, K., 1964. Zur Trematodenfauna von Nettapus c. coromandelianus in Indien. Angew. Parasit., 5: 228-241.

- 1966. Physidae und Planorbidae als Wirte in den Lebenszyklen einheimischer Notocotylidae (Trematoda: Paramphistomida). Z. Parasitenk., Berlin, 27: 210-239.

PIKE, A. W., 1967. Some stylet cercariae and a microphallid type in British freshwater molluscs. Parasitology, 57: 729-754.

- 1969 . Observations on the life cycles of Notocotylus triserialis Diesing, 1839, and $\mathrm{N}$. imbricatus (Looss. 1893) sensu Szidat, 1935. J. Helminth., 43: 145-165.

Rothschild, M., 1938. Notes on the classification of cercariae of the superfamily Notocotyloidea (Trematoda), with special reference to the excretory system. Novit. Zool., 41: 75-83.

Wesenberg-Lund, C., 1934. Contributions to the development of the Trematoda Digenea, 2. The biology of the freshwater cercariae in Danish freshwaters. K. dansk. Vidensk. Selsk. Skr., naturv. math., 9 (5), 3: 1-223.

Wikgren, B.-J., 1956. Studies on Finnish larval flukes. Acta zool. fenn., 91: 1-106.

WIŚNIEWSKI, W. L., 1958. The development cycle of Psilochasmus oxyuris Creplin, 1825. Acta Parasit. pol., 6: 273-287. 